Received 2016-09-04

Revised 2016-09-23

Accepted 2016-11-02

\title{
History of Leukemia: Diagnosis and Treatment from Beginning to Now
}

\author{
Sahar Mehranfar ${ }^{1,2,3}$, Sirous Zeinali ${ }^{4,5}$, Rana Hosseini ${ }^{6}$, Mozhdeh Mohammadian ${ }^{7}$, \\ Abolfazl Akbarzadeh ${ }^{8}$, Abbasali Hosein Pour Feizi ${ }^{2} \otimes$
}

\begin{abstract}
${ }^{1}$ Department of Molecular Medicine, School of Advanced Medical Science, Tabriz University of Medical Science, Tabriz, Iran ${ }^{2}$ Hematology and Oncology Research Center, Tabriz University of Medical Sciences, Tabriz, Iran ${ }^{3}$ Students Research Committee, Tabriz University of Medical Sciences

${ }^{4}$ Department of Molecular Medicine, Biotechnology Research Center, Pasteur Institute of Iran, Tehran, Iran

${ }^{5}$ Kawsar Human Genetics Research Center, Kawsar Genomics Center, Tehran, Iran

${ }^{6}$ Department of Community Medicine, Faculty of Medicine, Orumiye University of Medical Science, Orumiye, Iran

${ }^{7}$ Faculty of Paramedical Sciences, Mazandaran University of Medical Sciences, Sari, Iran

${ }^{8}$ Department of Medical Nanotechnology, Faculty of Advanced Medical Sciences, Tabriz University of Medical Sciences
\end{abstract}

\begin{abstract}
In 1845 , leukemia was known as a systemic illness; and it was more than 100 years later that the first report of a significant therapy for leukemia was published in 1948. Leukemia was known as a multifactorial disease rather than a single disease till 1900. In 1965, less than $1 \%$ of children with acute leukemia were predictable to have long-term survivors; today, approximately $80 \%$ of children and adolescents with acute lymphoblastic leukemia are cured, these achievements are due to the cooperative effort of researchers and physicians in the field. Despite this success, leukemia is still the leading cause of death globally. This review aims to elucidate the history of leukemia from the beginning of the 19th century when scientists defined unusual disorders of the blood cells, till present. Additionally, we tried to discuss the history of the diagnosis and treatment of leukemia with particular emphasis on acute leukemia. [GMJ.2017;6(1):12-22]
\end{abstract}

Keywords: Lymphoblastic Leukemia; Cancer; Myeloid Leukemia

\section{Introduction}

L eukemia comprises approximately $8 \%$ of the entire human cancers, and about half of them are classified as acute leukemia [1]. Acute leukemia is a malignant disorder due to clonal expansion of lymphoid and myeloid progenitors which involves both children and adults as the acute lymphoblastic leukemia (ALL) and acute myeloid leukemia (AML), respectively [2]. This review aims to elucidate

\section{GMJ}

2017 Galen Medical Journal

Tel/Fax: +98 7136474503

PO Box 7193616563

Email:info@gmj.ir the history of leukemia from the beginning of the 19th century when scientists defined unusual disorders of the blood cells, till present. After Robert Hooke (Figure-1) had published the first major work about advanced biological studies [3], Jan Swammerdam (1637-1680) observed the blood cells under the microscope for the first time in 1658 [4]. Anton van Leeuwenhoek (1632-1723), known as the father of microbiology (Figure-2), defined human red blood cells and blood flow in capillaries for

\footnotetext{
Correspondence to:

Abbasali Hosein Pour Feizi, Hematology and Oncology Research Center, Tabriz University of Medical Sciences, Tabriz, Iran

Telephone Number: +989144454610

Email Address : pourfeizi@yahoo.com
} 


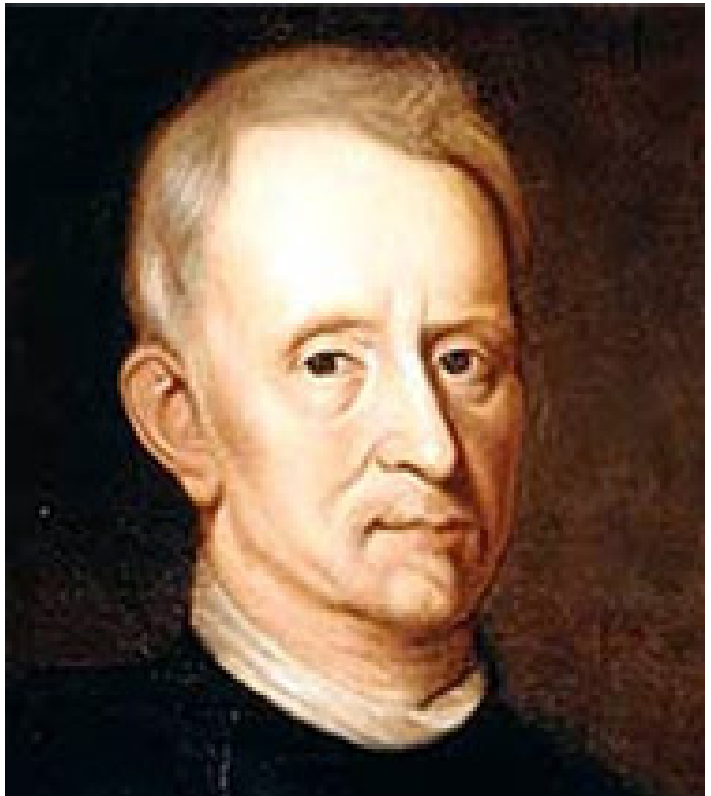

Figure 1. Rabert Hooke (18th July 1635 - 3rd March 1703) [75].

the first time [5-7]. His paper in 1674 included the first exact report of the red blood globules [8]. White blood cells were distinguished by Joseph Lieutaud (1703-1780); he published his main work on the lymphatic system and defined lymphocyte for the first time [9].

Current literature concerning the early understanding of leukemia is generally focused on one or two physicians that played a major role in this recognition. Velpeau, Alfred Donné, John Bennett and Rudolf Virchow (18211902) are four scientists who frequently refers to as "the one" who discovered leukemia; it is hard to say which of them took the first step [10-12]. However, our survey in published paper and books demonstrated that:

Peter Cullen (1769-unknown), born in Glasgow and Professor of Medicine in Edinburgh, was probably the first. He named of "splenitis actus" for splenitis with unexplainable milky blood; his article was published in 1811s [9, 13].

Maurice Duplay (1736-1820), a chef in Paris hospital in 1833, observed a severe fall of the blood at autopsy of a female patient [14]. Duplay (Figure-3) noticed that his findings were similar to that of Velpeau published in 1825. This case report had a minor contribution to the understanding of leukemia at that time [15].Collineau (1783-1860) and his col-

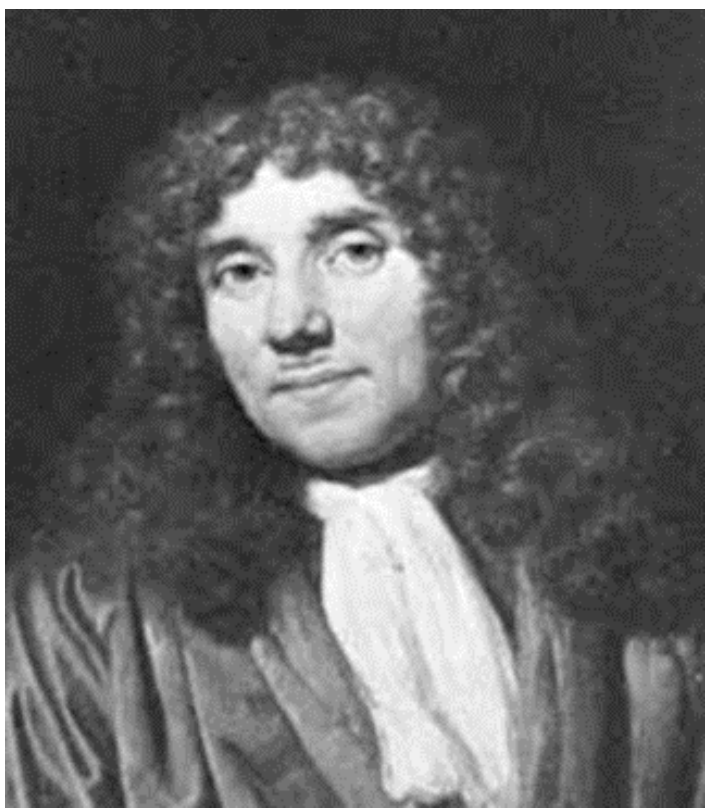

Figure 2. Anton van Leeuwenhoek (1632-1723) [6].

leagues, published an article on a likely case of leukemia in 1829. He believed that the pus, or milky fluid, was a result of the interim reduction of the blood, and lesion of the vessel walls [16]. In this case, they detected the milky blood, as was defined by Cullen and Velpeau before [5].

Alfred-Armand-Louis-Marie Velpeau (Figure-4), chairman at the University of Paris in 1833, published a case report (1827) with symptoms of swelling of the abdomen, fever, weakness, urinary stones and altered blood combination similar to pus-filled blood [15]. For the first time, he named the disease "leukemia" due to the increase in white blood cells $[15,17]$. Velpeau supposed that this specific disease was related to the circulatory system [15]. In 1839, Barth (1806-1877) had a similar case in Paris. After some time, Alexandre Donne found that half the blood cells consist of "white" globules; but this finding was not published till 1856 by Vidal (1825-93) [15].

Alfred DonneÂ (Figure-5) and Barth, discovered a maturation arrest of the white blood cells (1844); this was about six years before Bennett's or Virchow's publications. However, further clarification was given by Bennett (1845) and Virchow (six weeks later) independently [18]. He not only described leukemia but also he introduced the hypothesis 


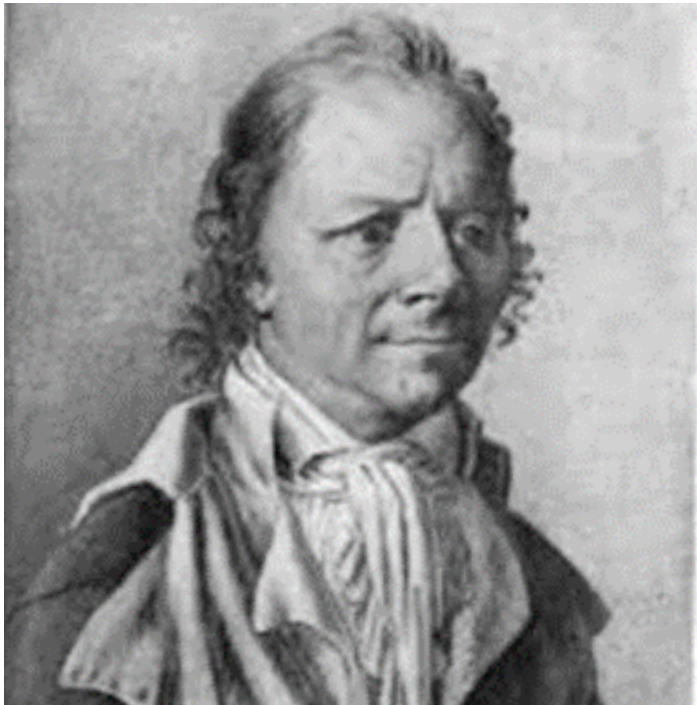

Figure 3. Maurice Duplay (1736-1820) [27].

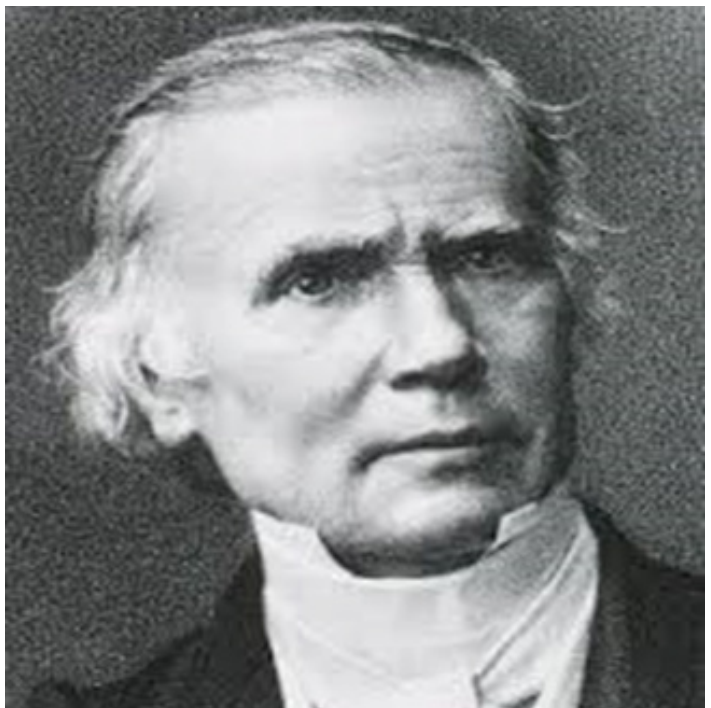

Figure 4. Alfred-Armand-Louis-Marie Velpeau (1795-1867) [24].

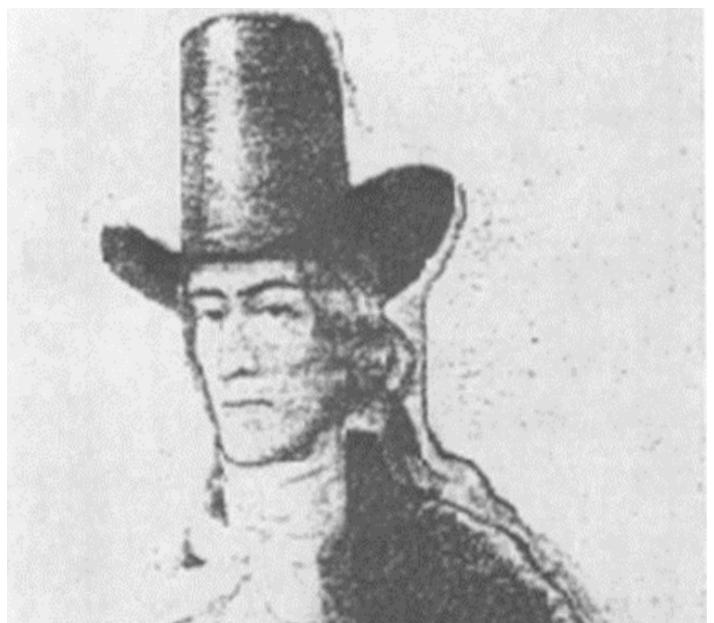

Figure 5. Alfred Frangois Donne (1801-1878) [5]. of festering matter in the blood; also, he discovered the third element of blood "platelets" in $1842[18,19]$ and presented microscopic workshops in medicine for the first time. His book "Cours de microscopie complémentaire" is still available $[19,20]$. He wrote a section titled "Alterations of the white blood cells" in this book $[5,21]$.

\section{History of Diagnosis of Leukemia}

Alfred Frangois Donne, in his publication concerning leukemia, stated that: "There are conditions in which white cells seem to be in excess in the blood. I found this fact so many times, it is so evident in certain patients, that I cannot conceive the slightest doubt in this regard. One can find in some patients such a significant number of these cells that even the least experienced observer is greatly impressed. I had an opportunity of seeing these in a patient under Rayer at the Hospital de la Charitd. The blood of this patient showed such some white cells that I though this blood was mixed with pus, but in the end, I was able to observe a clear-cut difference between these cells, and the white cells". For the first time, he found that leukemia was associated with abnormal cells [22].In 1843, Gabriel Andral (Figure-6), and William Addison (1802-1881) released the first reports documenting the of leukocytes in blood, at the same time $[18,22]$. David Craigie (1793-1866), teacher at the medicine school of Edinburgh since 1834, described that "chiefly because the occurrence of the case in many if not in all respects, similar to that of another physician in the same hospital, led me to anticipate similar results, and went far to confirm my conclusions deduced from the first case" [21]. He published about 30 papers on medical subjects [23].

Henry William Fuller (1820-1873) described the microscopical changes of blood cells and the structure of the abnormal globules that introduced by Donné Bennett and Virchow before. Fuller defined leukemia based on histological testing and combined them with the related symptoms [17]. He reached the first microscopic diagnosis of leukemia while the patient was alive (1846) [5]. Additionally, he reported a case of childhood leukemia for the first time; this significant finding was very im- 
portant because until that time children were specifically closed from hospitals in the belief that they were a carrier of infections. Leukemia was well-known when 50,000 deaths recorded in London, and 21,000 of them children were under the age of 10 years [13, 20, 23]. Hughes Bennett (Figure-7) was one of the external students of Donné's who graduated in 1837 [25]. He had presented the lectures on clinical microscopy reported by $\mathrm{Al}-$ fred Donnê̂A in Paris and helped Donne $\hat{A}$ 's to dominate the use of the microscope as a clinical instrument. Bennett printed a book on the utilization of the microscope for the diagnosis of diseases [26]. After Craigie's death, Bennett worked hard to involve microscope in studying of diseases. In 1843, Bennett clearly showed that the nuclei of the cells were consist of one large granule and sometimes of two or three smaller granules. In 1845, based on the microscopic assessments of blood, he described and called the disease leucocythemia $[3,5,27]$. The second case of leukemia was under treatment by Robert Christion (17971882) but was defined by Bennett who carried out the post-mortem analysis and presented blood films in his paper. Although Craigie's

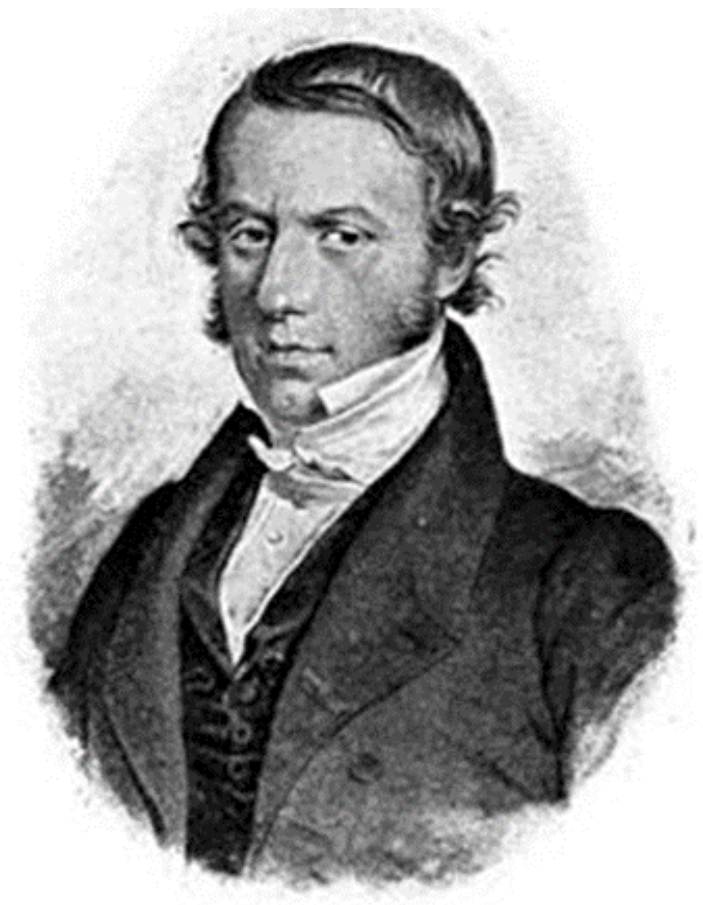

Figure 6. Gabriel Andral (1797-187) [25]. discover the first case, actually it has not been printed till Bennett worked it up in 1855. In 1846 the blood examination attracted further considerations [21]. The status of hematology from the 1850 s to the 1870 s was described by Lionel Beale (1828-1906). Beale demonstrated and described the various globules seen within the healthy blood (Figure-8) [27]. Virchow released his article on white blood cells in November 1845 whereas Bennett published his case report on leucocythemia, as an initial systemic disease of the blood, in October 1845. Virchow found pus-like matter in the aorta, that assume to suppress the red blood cells. Virchow called this disease as 'leukämie' in German, in 1847. After checking up few leukemia cases, he has explained the relation between splenic and lymphatic leukemia as well as white and red blood cell balance for the first time. This major finding was very significant in the understanding of leukemia $[3,10,13,17]$.

In 1847, T. K. Chambers (1819-1889) reported a large number of granular, irregular, spheroidal bodies, two or three times the size of blood corpuscles in the blood of a patient with large spleen; these were myelocytes.

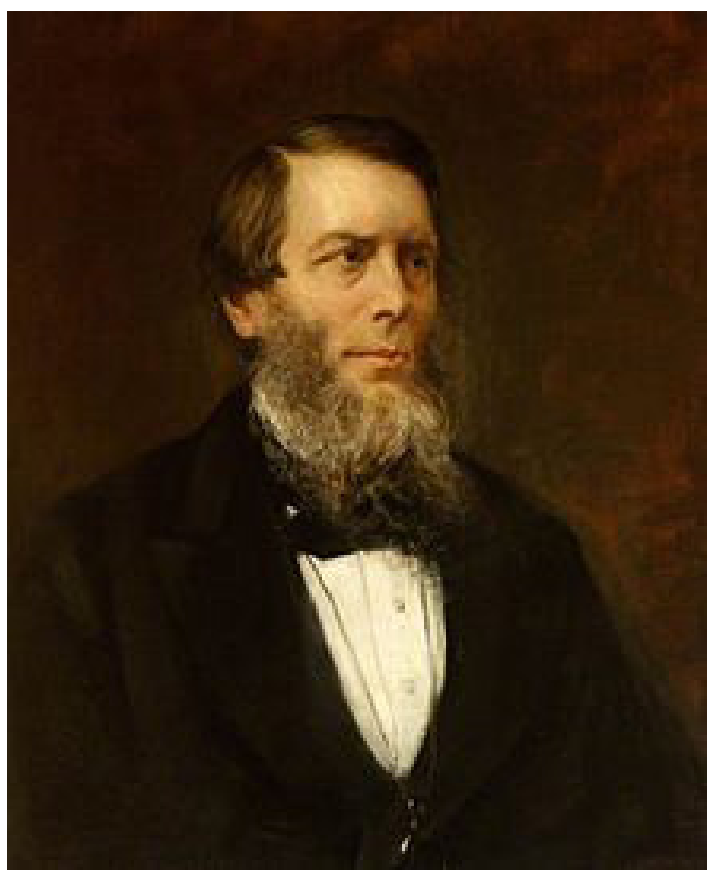

Figure 7. John Hughes Bennett (31 August 1812 25 September 1875) [24]. 


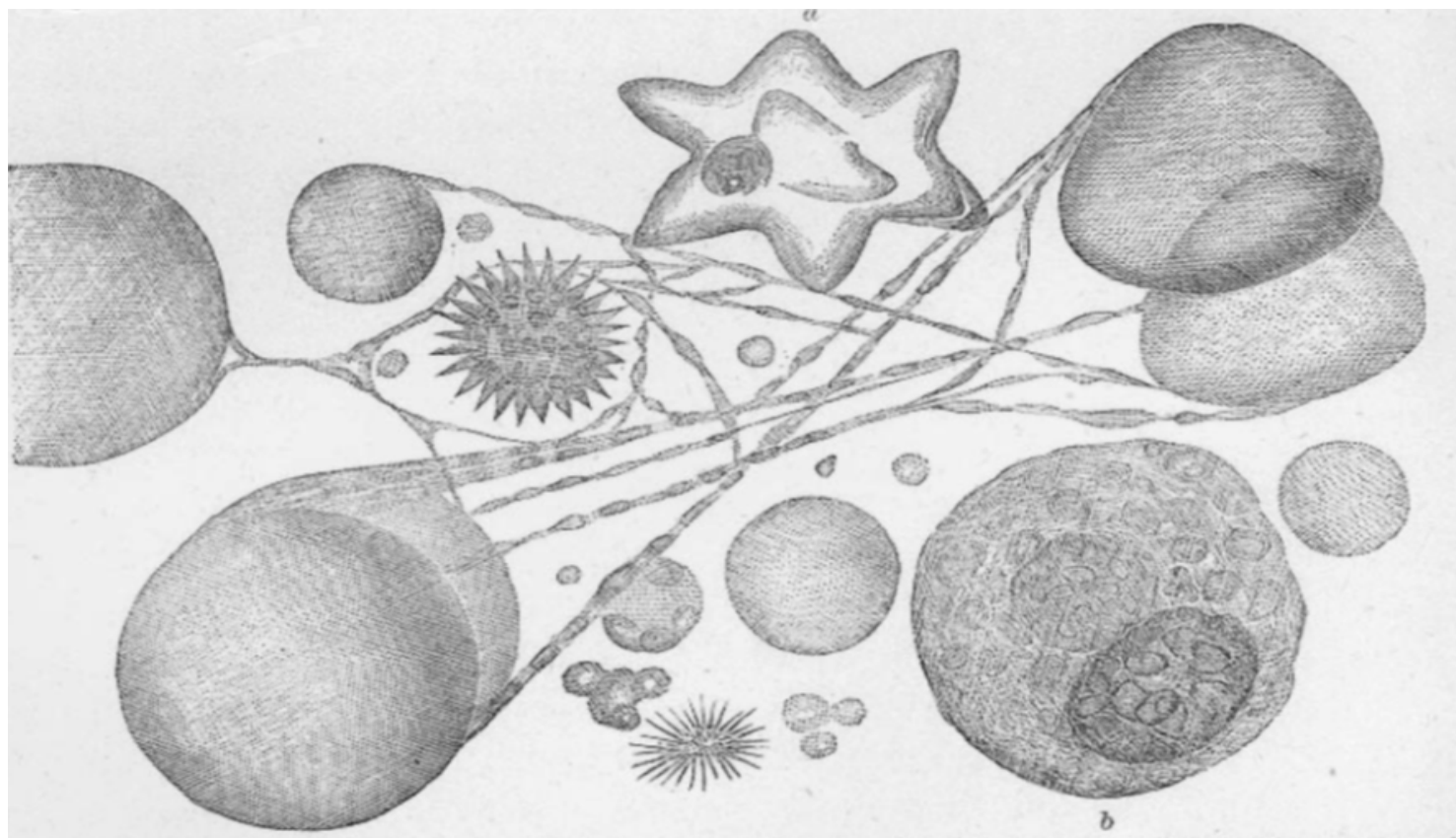

led and white eorpuscles in blood from the fnger. $\times 2800$ linear. The large smooth circular bodies are the rect crpuscles. Three very small red corpuscies are less than the son of an inch in diameter. The smallest particles ire composed of matter like that of which the white blood corpriscle (b) consists Threads of tibrine undersoins reasulation are observed between the corpuscles in the uprer and jower part of the fleld, $\boldsymbol{a}$, red corpuscle, exhi. nitine andular profections. Below it, and to the left, Is another, with still more pointed processes. September, $18 \mathrm{~s}$.

Figure 8. Sketch of red and white cell in blood. The picture was originally painted by Beal on September 1863 [25].

In 1847, Virchow defined two forms of leukemia, splenic and lymphatic. In 1865, John Heim announced the term "pseudo-leukemia" for the lymphatic glands which presented the picture of leukemia without the blood changes; now it called aleukemic phase of leukemia. Magnus Huss (1807-1890) recommended that we should be differentiating between leukocytosis and leukemia when the number of white cells reached 1 to 20 red cells. This quantitative criterion was changed by Ehrlich when he classified the white cells [13].

Ernst Christian Neumann (1834-1918) showed that the bone marrow (BM) was unusual in leukemia [9]. He reported the main discovery in 1868 about changes in the BM and relation between these changes and leukemia [6]. He continued to study for years until in 1872 he notified that leukemia was a disease of the marrow [28]. Six years later, he was classified melogenic, splenic and lymphatic types of leukemia [29]. Before him, Nikolaus Friedreich defined and used the term of "acute leukemia" for the first time [30]. Neumann examined BM sample from one dead patient; he saw colored "dirty green-yellow" cell which was different from the normal red cells. In 1868, this finding allowed Neumann to explain that BM was the source of blood cells leukemia and also it was responsible for these abnormal blood cells $[3,5]$. In his papers, he explained that erythropoiesis and leukopoiesis happened in the BM. This finding was not accepted for many of years. He was the first one who suggests the BM as a blood-forming organ with a common stem cell for all hematopoietic cells"'[20].

Paul Ehrlich (1854-1915) in 1877 reports main results of leukemia for the first time and also gave a clear description of the nucleus, the cytoplasm and other of blood cells [30]. In 1879 , when he was at age 25 , he spread his technique for dyeing blood films and his procedure for differential blood cell counting and classified them, he started this work in 1877 $[17,8]$. Maybe it was the first time that the red cells, a cell in the hematopoietic series, had been well-defined; and it was the earliest use of the opinion of the stem cell. Ehrlich suggested that leukemia was the main disease of 
the hemopoietic system [13] and his discovery opened the morphological date of hematology; therefore, the barrier of progress in this area was broken [6]. In 1927, the BM aspiration was first well-defined by Mikhail Arinkinin, and in 1933, R. P. Custer introduced the BM biopsy examination as a new diagnostic procedure [6].

\section{Leukemia in Children}

Childhood acute leukemia (ALL) is one of the diseases that provided a good progress of cancer research and treatment [5]. By the 1920's it was recognized that the disease commonly involves children [9]. Until the 1930s it was thought-out a rare disease; but by 1960 , information collected in Great Britain showed that leukemia had become the second cause of death in children $[6,9,23]$. There was a delay in the acknowledgment of the disease in children; it was reported by Biermer in 1861 and Birch-Hirschfield in 1878 [31].

William Hewson who has been nominated as one of the fathers of hematology was eminent for describing the leukocytes for the first time and displaying that coagulation happened in the plasma [32].

Julius Bizzozero recognized the BMs as the site of blood formation. Also, he was one of the pioneers of working on the platelet [33, 34].Dying of blood smears was established by Paul Ehrlich in 1877 while he was a medical student; he also recognized neutrophils, basophils, and eosinophils. This method allowed the recognition of many blood diseases such as leukemia and different types of anemia which defined by morphological definitions [13].In 1825, W.P. De Wees wrote a chapter on the physical and medical treatment of children, the first American pediatric textbook [35]. In 1924 Lucas and his assistant, E.C. Fleichner wrote six chapters on the blood that was the first complete American propagation on childhood hematology [36]. In 1889, Georges Hayem thoroughly described the blood image at birth in one of the oldest hematological texts, he was a forerunner in the field of hematology and is remembered for his studies on leukocytes and erythrocytes [37]. In 1917, Gordon Ward presented an infective theory of acute leukemia and collected 1457 cases of leukemia of all types; it was the first reliable epidemiological study about leukemia [38]. Guido Fanconi (1892-1979) and his assistant, conducted studies of the peripheral blood and BM findings in leukemia, thrombocytopenia, several anemias, and neutropenia [8]. Ferruchio Zibordi published the first European textbook of pediatric hematology in 1924. In the $1950 \mathrm{~s}$, a section of pediatric oncology was established by Odile Schweisguth who was a famous pioneer pediatric oncologist in Europe [39]. In 1940, H. Dargeon reported that the mean of survival after diagnosis of ALL was less than 3 months. In 1965, a study was done by Joseph Burchenal and Lois Murphy; they recognized that only 71 children had survived, with or without disease, for more than 5 years [40].

\section{History of Leukemia Treatment}

A new finding by Pasteur, Koch in fields of bacteriology and immunology aided to discovering the new aspects in leukemia's etiology and response to treatment. Formerly, leukemia was recognized only as a chronic disease, while acute and nature form was soon discovered [14]. The source of the blood cells was discovered at the end of the nineteenth century which led to the classification of the leukemia subtypes. As these findings were not sufficient for treatment of the disease, there was still a lack of any form of effective therapy in the treatment of leukemia [6].

\section{Arsenic and Nitrogen Mustard}

Then Leukemia was accepted as a chronic disease, and several drugs were used for its treatment; for example, quinine for fever, opium for diarrhea and pain, iron for anemia and iodine as an antibacterial agent. Arsenic first employed by Thomas Fowler in 1786, for reducing fevers and headaches [41]. Later, in 1865 , arsenic was used in the treatment of leukemia by Lissauer for the first time [42]. In fact, Arsenic was the first agent with some beneficial use in the treatment of certain forms of leukemia [43].

In 1942 the first clinical report on nitrogen mustard on lymphoid tissues was done by Gilman and Philips on American patients, but because of the war situation, they have not 
published any paper till 4 years later [44].

Three paper published in the same year (1946) (Rhoads; Goodman et al.; Jacobson et al.). All findings showed that nitrogen mustard had a positive effect on Hodgkin's lymphoma, chronic leukemia, and lymph sarcoma $[6,45,46]$.Within the same period in Britain, John Wilkinson had been worked on nitrogen mustards with F. Fletcher since 1942; but they were unable to release any paper until 1947. Their findings of treatment of patients with leukemia with nitrogen mustard were in agreement whit the results that were obtained in the America [47]. These results showed beneficial effects of nitrogen mustard on lymphomas rather than leukemia, even in some patients who was resistant to X-ray therapy [44].

\section{Blood Transfusion}

Blood transfusion was done on the patient with leukemia by Callender in 1873, for the first time [7]. The obstacle of coagulation of blood after transfusion from donor to recipient unraveled by Karl Landsteiner[48]. Blood transfusion was not accepted as a treatment for leukemia till Professor James Blundell improved the safe method of transfusion [43, 49]. Phlebotomy, blood and blood products transfusion and other therapies are used since $1950[8,48]$.

\section{$X$-ray}

The discovery of X-ray, in 1895 by Wilhelm Rontgen, was lightening a hope to a new treatment for leukemia [49]. X-ray therapy was applied for leukemia treatment in 1903 by Nicholas Senn for the first time; he believed that microbes were the cause of leukemia and irradiation can injure them [50].

\section{Radiotherapy}

At the end of the 1890s, was began to use for treatment of extramedullary leukemia and splenomegaly or lymphadenopathy [51].

\section{Folic Acid}

Sidney Farber observed and believed that tumors with rapid growth such as ALL, induced by of folic acid. Accordingly, he theorized that folic acid antagonists could inhibit tumor growth. Later he reported numbers of temporary remissions in children with ALL but none of them were really cured [53]. In 1943 folic acid was known as an important agent in hemopoiesis [52, 53]. Later, in 1944, Lewisohn found that it had an inhibitory effect on tumors cells in rats [54]. In 1946, subbaRow used folic acid on patients for the first time [55]. In 1947 Sidney Farber cooperation's with SubbaRow showed that folic acid antagonists could have an effective impact on the treatment of children with acute leukemia. Results showed that children improvement was temporary but not permanent. In clinical trials conducted in 1947 and 1948 on 16 infants and children with acute leukemia, aminopterin was administered via intramuscular injection; this intervention resulted achieving clinical, hematological and pathological evidence of major improvement in 10 patients; although it was temporary [56].

\section{Adrenal Corticosteroids}

The therapeutic value of the adrenal corticosteroids was founded in 1949 by Farber and Pearson [56-58]. Soon it was found out that it could increase the rate of remissions in children with acute leukemia $[31,59,60]$.

\section{Chemotherapy}

The modern therapy of leukemia started by Sidney Farber in 1948 by introducing acid folic as an anti-cancer therapy [5, 61]. After Farber's publication, new anti-leukemic drugs were offered. One of the most famous of them was the purine antagonist, 6-mercaptopurine that positive effective in children leukemia was shown by Burchenal and Lois Murphy in 1953. Later, other antileukemic drugs were introduced such as 1-asparaginase in 1961, vincristine in 1962 [38].

Studies about the treatment process by new drug therapy have shown that the median survival time and long-term survival significantly improved since 1964 to 2014 . Median survival time improved from 2 months to more than 10 years, and long-term survival reached more than $90 \%$ from about 5\%[8]. Despite these finding, about 40-45 years passed without the discovery of any other effective therapies for leukemia $[35,36,54,55]$. 


\section{Combination Therapy}

In the late 1950s, James Holland, Emil Freireich, and Emil Frei and their colleagues started combination therapy (prednisone, vincristine, methotrexate, and 6-Mercaptopurine); they achieved time long-term remissions and cures in children with ALL for first [51, 62, 63]. The combination therapy for pediatric ALL has been improved over time which results in complete remission (CR) and long-term survival [64].

Treatment in adults is almost performed by the same drugs as used in pediatric ALL. More than $90 \%$ of adults with ALL get CR with multidrug chemotherapy [65].

\section{Targeted Therapy}

Our understandings about molecular pathology of disease, help physicians to selected better treatment protocol for their patients, more recently, targeted therapies have been advanced by recognized some genetic lesions. Targeted therapies have led to major improvements in patient outcomes while reducing the toxicity caused by chemotherapy [66].

Targeted therapy was done on chronic myelogenous leukemia (CML), one of the chronic myeloproliferative neoplasms, for the first time [67].

Till the late 1990s drugs used in cancer treatment, except for hormone drugs, the effect on both normal and abnormal cells; therefore, chemotherapy drugs were also cytotoxic for normal cells [68]. Targeted therapies resolve this, as they do not affect normal cells. It works in several ways such as affecting the control of growth, division and spread of cancer cells [69].Advances in targeted therapy for treatment of leukemia bright sure for leukemic patients and improved their outcomes [70].

\section{Immunotherapy}

Today immunotherapy such as expression CD markers used for patients failed by induction therapies $[63,71]$. Currently, monoclonal antibody therapy has become a critical component of a clinical treatment procedure for a variety of diseases including leukemia. For example, we can name Gemtuzumab for CD33 positive AML [72].

\section{Stem-cell Transplantation}

There are 3 type of BM transplantation including autologous BM transplant, allogeneic BM transplant, and umbilical cord blood transplant. Hematopoietic stem cells are killed in people who receive chemotherapy and radiation; stem cell transplantation helps to restore their BM reservoir with normal hematopoietic stem cells [73]. The increasing success of BM transplantation caused to create a large database of HLA-typed volunteers, so that helped patients have alternative options when not matching donors in their families. Laura Graves from Colorado with acute leukemia became the first leukemia patient to be treated with non-relative BM transplant [74].

\section{Conclusion}

Studies of leukemia in the laboratory and the clinic have generated many new aspects and therapies that will undoubtedly continue to be rapidly applied to the other forms of systemic cancer, particularly the concept of narrowly targeted personalized therapy that has proven so effective. It seems likely others types of leukemia will eventually approach the success achieved with acute promyelocytic leukemia, CML, and pediatric ALL.

Advance in the treatment of leukemia happened as a result of increased awareness about pathology and target therapy. The historical process of diagnosis and treatment of hematologic malignancies show that progress in the treatment of other malignancies also passes through hematologic malignancies.

\section{Acknowledgements}

The author thank the Hematology \& Oncology Research Center, Faculty of Medicine, Tabriz University of medical sciences for all support provided (study ID: 93/4-10/4).

\section{Conflict of Interest}

There was no conflict of interest. 
1. Jahedi M, Shamsasenjan K, Sanaat Z, Aliparasti M, Almasi S, Mohamadian M, et al. Aberrant Phenotype in Iranian Patients with Acute Myeloid Leukemia. Adv Pharm Bull. 2014;4(1):43.

2. Einollahi N, Alizadeh S, Dashti N, Nabatchian F, Zare Bovani M, Abbasi S, et al. Serum lipid profile alterations in acute leukemia before and after chemotherapy. Iran Blood Cancer j. 2013;6(1):3-9.

3. Hooke R. 1665. Micrographia London. 1961.

4. Piller G. The history of leukemia: a personal perspective. Blood cells. 1992;19(3):521-9; discussion 30-5.

5. Kampen KR. The discovery and early understanding of leukemia. Leuk Res. 2012;36(1):6-13.

6. Piller GJ. Leukaemia-a brief historical review from ancient times to 1950 . Br J Haematol. 2001;112(2):282-92.

7. Pasteur L. Louis Pasteur. Société des traités religieux de Lausanne; 1913.

8. Wintrobe MM. Blood, pure and eloquent. McGraw-Hill; 1980.

9. Hewson W, Falconar M. Experimental inquiries. J. Johnson; 1774.

10. Degos L, Hirst W, Buggins A, Mufti G, Mercier E, Branger B, et al. John Hughes Bennett, Rudolph Virchow... and Alfred Donne: the first description of leukemia. Hem J. 2000;2(1):1-.

11. Lichtman MA. Battling the hematological malignancies: the 200 years' war. Oncologist. 2008;13(2):126-38.

12. Seufert W, Seufert WD. The recognition of leukemia as a systemic disease. J Hist Med Allied Sci. 1982;37(1):34-50.

13. Ehrlich P. Beiträge zur Kenntniss der Anilinfärbungen und ihrer Verwendung in der mikroskopischen Technik. Archiv für mikroskopische Anatomie. 1877;13(1):26377.

14. Duplay M. Observation d'une altération très grande du sang. Arch Gen Med, Paris, II. 1834;6:223-34.

15. Velpeau A. Sur la resorption du pusaet sur l'alteration du sang dans les maladies clinique de persection nenemant. Premier observation. Rév Méd. 1827;2:216.

16. Delasiauve LJF. J Med Mentale. 1868.

17. Virchow R. Zur pathologischen Physiologie des Bluts. Virchows Arch Pathol Anat Physiol Klin Med. 1847;1(3):547-63.
18. Andral G. Essai d'hématologie pathologique.14th ed. Paris, Masson; 1843.

19. Holt LE. The diseases of infancy and childhood. D. Appleton \& Company; 1897.

20. Zech NH, Shkumatov A, Koestenbauer S. The magic behind stem cells. J Assist Reprod Genet. 2007;24(6):208-14.

21. Rolleston H. The history of haematology. J R Soc Med. 1934;27(9):1161.

22. Addison W. Experimental and practical researches on inflammation, and on the origin and nature of tubercles of the lungs. Churchill; 1843.

23. Virchow R. Gesammelte abhandlungen zur wissenschaftlichen medicin. Meidinger; 1856.

24. Piller GJ. The history and presentation of leukaemia 1845-1960.UK, NY: Doctoral dissertation, Open University; 1992.

25. Hajdu SI. The discovery of blood cells. Ann Clin Lab Sci. 2003;33(2):237-8.

26. Bennett JH. On the employment of the microscope in medical studies. 1841.

27. Bennett JH. Case of Hypertrophy of the Spleen and Liver: In which Death Took Place from Suppuration of the Blood. Stark and Comp; 1845.

28. Neumann E. Ein neuer fall von Leukamie mit erkrankung des knochenmarks. Arch Heilkunde. 1872;13:502-8.

29. Neumann E. Ueber myelogene leukämie. 1878.

30. Friedreich N. Ein neuer fall von leukämie. Virchows Arch. 1857;12(1):37-58.

31. Virchow R. Normal and pathological newformation. Cell Pathol trans. 1858.

32. Wintrobe MM. Clinical hematology. Acad Med. 1962;37(1):78.

33. Osler W. An account of certain organisms occurring in the liquor sanguinis. R Soc Lond. 1873;22(148-155):391-8.

34. 34. Bizzozero J. Ueber einen neuen Formbestandtheil des Blutes und dessen Rolle bei der Thrombose und der Blutgerinnung. Archiv für pathologische Anatomie und Physiologie und für klinische Medicin. 1882;90(2):261-332.

35. Dewees WP. A treatise on the physical and medical treatment of children. Blanchard and Lea; 1858.

36. Lippman HS. A morphologic and quantitative study of the blood corpuscles in the new-born period. Am J Dis Child. 1924;27(5):473-526. 
37. Hersh EM, Bodey GP, Nies BA, Freireich EJ. Causes of death in acute leukemia: A ten-year study of 414 patients from 1954-1963. Jama. 1965;193(2):105-9.

38. Burchenal JH, Murphy M, Ellison R, Sykes $\mathrm{M}$, Tan T, Leone L, et al. Clinical evaluation of a new antimetabolite, 6-mercaptopurine, in the treatment of leukemia and allied diseases. Blood. 1953;8(11):965-99.

39. Pearson HA. History of pediatric hematology oncology. Pediatr Res. 2002;52(6):979-92.

40. Burchenal JH. Long $\square$ term survivors in acute leukemia and Burkitt's tumor. Cancer. 1968;21(4):595-9.

41. Kastner P, Dupuis A, Gaub M-P, Herbrecht R, Lutz P, Chan S. Function of Ikaros as a tumor suppressor in B cell acute lymphoblastic leukemia. Am J Blood Res. 2013;3(1):1-13.

42. Bairey O, Vanichkin A, Shpilberg O. Arsenic $\square$ trioxide $\square$ induced apoptosis of chronic lymphocytic leukemia cells. Int J Lab Hematol. 2010;32(1p1):e77-e85.

43. Böttger H. Handelsrecht, Strafrecht und das gerichtliche Verfahren. Die ApothekenGesetzgebung des deutschen Reiches und der Einzelstaaten auf der Grundlage der allgemeinen politischen, Handels-und Gewerbegesetzgebung dargestellt. Springer; 1880. p. 128-92.

44. Gilman A, Philips FS. The biological actions and therapeutic applications of the B-chloroethyl amines and sulfides. Science. 1946;103(2675):409-36.

45. Rhoads CP. Nitrogen mustards in the treatment of neoplastic disease: Official statement. J Am Med Assoc. 1946;131(8):656-8.

46. Iacobucci I, Storlazzi CT, Cilloni D, Lonetti A, Ottaviani E, Soverini S, et al. Identification and molecular characterization of recurrent genomic deletions on $7 \mathrm{p} 12$ in the IKZF1 gene in a large cohort of BCR-ABL1-positive acute lymphoblastic leukemia patients: on behalf of Gruppo Italiano Malattie Ematologiche dell'Adulto Acute Leukemia Working Party. Blood. 2009;114(10):2159-67.

47. Wilkinson J, Fletcher F. Effectof $\beta$-Chlorethylamine Hydrochlorides in leukemia, Hodgkin's Diseases, and Polycythemia Vera: report on eighteen cases. Lancet. 1947;250(6476):540-5.

48. Freireich EJ, Wiernik PH, Steensma DP. The leukemias: a half-century of discovery. J Clin Oncol. 2014;32(31):3463-9.

49. Blundell J. The after management of floodings and on transfusion. Lancet. 1828; 13:673.

50. Senn N. Case of Splenomedullary Leukaemia Successfully Treated by the Use of the Roentgen Ray. 1903.

51. Frei 3rd E, Karon M, Levin RH, Freireich EJ, Taylor RJ, Hananian J, et al. The effectiveness of combinations of antileukemic agents in inducing and maintaining remission in children with acute leukemia. Blood. 1965;26(5):642.

52. Pfiffner J, Binkley S, Bloom E, Brown R, Bird O, Emmett A, et al. Isolation of the antianemia factor (vitamin $\mathrm{Bc}$ ) in crystalline form from liver. Science. 1943;97(2522):4045.

53. Stokstad E. Some properties of a growth factor for Lactobacillus casei. J Biol Chem. 1943;149(2):573-4.

54. Leuchtenberger C, Lewisohn R, Laszlo D, Leuchtenberger R. "Folic Acid" a Tumor Growth Inhibitor. Exp Biol Med. 1944;55(3):204-5.

55. 55. SubbaRow Y. Folic acid. Academy; 1946.

56. Farber S, Diamond LK, Mercer RD, Sylvester Jr RF, Wolff JA. Temporary remissions in acute leukemia in children produced by folic acid antagonist, 4-aminopteroyl-glutamic acid (aminopterin). N Engl J Med. 1948;238(23):787-93.

57. Farber S, Schwachman H, Toch R, Downing $\mathrm{V}$, Kennedy BH, Hyde J, editors. The effect of ACTH in acute leukemia in childhood. First Clinical ACTH Conference New York: Blakiston; 1950.

58. Pearson O, Eliel L, Rawson RW, Dobriner $\mathrm{K}$, Rhoads C. Acth and cortisone induced regression of lymphoid tumors in man. A preliminary report. Cancer. 1949;2(6):943-5.

59. Elion GB, Burgi E, Hitchings GH. Studies on condensed pyrimidine systems. IX. The synthesis of some 6-substituted purines. J Am Chem Soc. 1952;74(2):411-4.

60. Elion GB, Hitchings GH, Vanderwerff $H$. Antagonists of nucleic acid derivatives VI. Purines. J Biol Chem. 1951;192(2):505-18.

61. Freireich EJ. The history of leukemia therapy - a personal journey. Clin Lymphoma Myeloma Leuk. 2012;12(6):386-92.

62. Frei E, 3rd, Holland JF, Schneiderman MA, Pinkel D, Selkirk G, Freireich EJ, et al. A comparative study of two regimens of combination chemotherapy in acute leukemia. Blood. 1958;13(12):1126-48.

63. Grupp SA, Kalos M, Barrett D, Aplenc R, Porter DL, Rheingold SR, et al. Chimeric 
antigen receptor-modified T cells for acute lymphoid leukemia. N Engl J Med . 2013;368(16):1509-18.

64. Möricke A, Zimmermann M, Reiter A, Henze G, Schrauder A, Gadner H, et al. Long-term results of five consecutive trials in childhood acute lymphoblastic leukemia performed by the ALL-BFM study group from 1981 to 2000. Leukemia. 2010;24(2):265-84.

65. Thomas DA, O'Brien S, Faderl S, GarciaManero G, Ferrajoli A, Wierda W, et al. Chemoimmunotherapy With a Modified Hyper-CVADand Rituximab Regimen Improves Outcome in De Novo Philadelphia Chromosome-Negative Precursor B-Lineage Acute Lymphoblastic Leukemia. J Clin Oncol. 2010:JCO. 2009.26. 9456.

66. Druker BJ, Lydon NB. Lessons learned from the development of an abl tyrosine kinase inhibitor for chronic myelogenous leukemia. J Clin Invest. 2000;105(1):3.

67. Dobbelstein M, Moll U. Targeting tumoursupportive cellular machineries in anticancer drug development. Nat Rev Drug Discov. 2014;13(3):179-96.

68. Druker B, Talpaz M, Resta D, Peng B, Buchdunger E, Ford J, et al., editors. Clinical efficacy and safety of an ABL specific tyrosine kinase inhibitor as targeted therapy for chronic myelogenous leukemia. Blood; 1999: AMER SOC HEMATOLOGY 1200 19TH ST, NW, STE 300, WASHINGTON, DC 20036-2422 USA.
69. Greaves M, Maley CC. Clonal evolution in cancer. Nature. 2012;481(7381):306-13.

70. Schultz KR, Bowman WP, Aledo A, Slayton WB, Sather H, Devidas M, et al. Improved early event-free survival with imatinib in Philadelphia chromosome-positive acute lymphoblastic leukemia: A children's oncology group study. J Clin Oncol. 2009;27(31):5175-81.

71. Leung W, Campana D, Yang J, Pei D, Coustan-Smith E, Gan K, et al. High success rate of hematopoietic cell transplantation regardless of donor source in children with very high-risk leukemia. Blood. 2011;118(2):223-30.

72. Sievers EL, Larson RA, Stadtmauer EA, Estey E, Löwenberg B, Dombret H, et al. Efficacy and safety of gemtuzumab ozogamicin in patients with CD33-positive acute myeloid leukemia in first relapse. $\mathrm{J}$ Clin Oncol. 2001;19(13):3244-54.

73. Mohammadian M, Shamsasenjan K, Lotfi Nezhad P, Talebi M, Jahedi M, Nickkhah H. Mesenchymal stem cells: new aspect in cellbased regenerative therapy. Adv Pharm Bull. 2013;3(2):433-7.

74. Dick D. Human acute myeloid leukemia is organized as a hierarchy that originates from a primitive hematopoietic cell. Nat Med. 1997;3:730-7. 